\title{
PENELITIAN
}

\section{ANALISIS MASALAH KEPERAWATAN PADA KLIEN KEGANASAN HEMATOLOGI YANG MENDAPATKAN TERAPI MEDIK KEMOTERAPI}

\author{
Agung Waluyo*
}

\begin{abstract}
Abstrak
Penelitian ini bertujuan menggali masalah/ diagnosa keperawatan yang sering ada pada klien keganasan hematologi yang mendapatkan kemoterapi. Desain penelitian qualitatif ini phenomenology. Peneliti mengeksplorasi bagaimana klien kanker yang mendapatkan kemoterapi menyampaikan pengalaman dan masalah seputar dampak pemberian kemoterapi. Responden ( $\mathrm{n}=10)$ berpendidikan SMP sampai perguruan tinggi. Mereka semua pria berusia 14-61 tahun. Diagnosa medis dari pasien tersebut adalah limfoma malignum hodgkin, limfoma malignum non hodgkin, anemia aplastik, dan leukemia limfoblastik akut. Penelitian ini menemukan tujuh masalah/ diagnosa keperawatan. Rekomendasi yang dapat disampaikan adalah bahwa informasi yang ada dapat digunakan sebagai data dasar bagi penelitian selanjutnya, khususnya penelitian tentang bentuk asuhan keperawatan yang diberikan pada klien kanker yang mendapatkan kemoterapi. Selain itu perlu juga dilakukan penelitian yang membahas persepsi perawat yang merawat klien kanker yang mendapatkan kemoterapi, sehingga diperoleh persepsi yang berimbang. Penelitian yang sama dengan setting ruangan atau rumah sakit yang berbeda diperlukan juga untuk memperkaya hasil yang didapatkan tentang masalah keperawatan klien kanker dengan pemberian kemoterapi.
\end{abstract}

Kata kunci: masalah keperawatan, keganasan hematologi, kemoterapi.

\section{Abstract}

The purpose of this study was to identify the nursing problem of patient with hematology cancer who were undergoing chemotherapy. The design of this qualitative research was phenomenology, which was useful to get the pure \& broad perspective on how patients experience to the chemotherapy \& what were the problems arise from the side effect of chemotherapy. Ten respondents participated the study, and some of them were well educated from some universities and the remain were only graduated from junior high school (SMP). All respondents were male with the range of age from 14 years old to 61 years old. They have been diagnosed with Lymphoma Malignum non Hodgkin, Lymphoma Malignum Hodgkin, Anemia Aplastic and Acute Leukemia Lymphoblastic. The findings identified 7 nursing problem/ diagnoses. Some recommendation of the study were proposed that this study should be followed by another one especially those which related to the nursing care plans of the hematology cancer patient who undergone chemotherapy. It might be better to do the same study with broader are of hospital and more respondents that could increase the validity of this study. The study of nurse perception on the hematology cancer patient on how they perceive patient problem could enriched the result of this study.

Key words: nursing problem, the hematology cancer, chemotherapy

\section{LATAR BELAKANG}

Keganasan merupakan fenomena dari perkembangan sel yang tidak terkontrol yang mengakibatkan beberapa gangguan pada sistem di tubuh manusia. Gangguan tersebut umumnya cukup serius bahkan dapat mengganggu fungsi organ yang terkena, sehingga keseimbangan dan keselarasan berbagai sistem dalam tubuh manusia akan terganggu (McLaughlin, 1998).

Keganasan hematologi seperti leukemia memiliki masalah yang cukup serius meliputi masalah primer dan sekunder. Masalah primernya antara lain terjadi pada sumsum tulang yang mengakibatkan pansitopeni, yaitu trombositopenia, anemia, dan leukopenia. Pada kondisi ini pasien menjadi sangat rentan karena pasien dapat dengan mudah mengalami perdarahan, infeksi, dan kelemahan. Masalah sekunder yang dapat terjadi pada pasien ini adalah gangguan sistem persarafan (sakit kepala, peningkatan tekanan intra kranial, paralisis), gangguan sistem muskuloskeletal, dan sistem lain yang sangat vital bagi pasien (Copstead, 2000). 
Para ahli terus berusaha menemukan terapi yang efektif untuk memperlambat pertumbuhan kanker atau bahkan menghentikannya dan dengan efek samping yang paling minimal. Kemoterapi mempunyai efek samping yang tidak sedikit. Sutandio (1999) menjelaskan bahwa kemoterapi tidak selektif kerjanya. Dampak dari terapi itu beberapa sel-sel normal/ sehat yang memiliki aktifitas pembelahan yang tinggi seperti sel-sel sumsum tulang, akar rambut, kulit, kelenjar kelamin akan terhambat.

Pemberian kemoterapi pada pertama kali (seri pertama) sering menimbulkan masalah yang cukup serius, baik karena efek samping maupun dampak dari ketidaksiapan klien. Hal ini bisa disebabkan informasi tentang kemoterapi yang diberikan kurang memadai atau kurang dipahami klien. Dengan demikian perlu diketahui masalah keperawatan apa yang akan muncul pada klien tersebut terutama ketika klien mendapatkan kemoterapi untuk pertama kali.

Waluyo (1999) dalam tesisnya mengemukakan bahwa perawat mempersepsikan klien yang mendapatkan kemoterapi mengalami masalah fisik seperti di atas dan juga beberapa masalah psikososial. Namun secara eksplisit masalah keperawatan pada klien yang mendapatkan kemoterapi (khususnya klien dengan keganasan hematologi, seperti leukemia) belum ada peneliti yang mengeksplorasi lebih jauh. Menurut McLaughlin (1998) kasus keganasan hematologi memiliki kecenderungan peningkatan sehingga masalah keperawatan yang dapat timbul menyertai pemberian kemoterapi perlu diketahui oleh para perawat. Masalah keperawatan menjadi penting diketahui karena perawat dapat mengantisipasi dan mengintervensi masalah klien (khususnyakeganasan hematologi) yang mendapatkan kemoterapi.

Antisipasi perawat dapat berupa pemberian kontribusi dalam meningkatkan kualitas hidup klien sehingga asuhan keperawatan yang diberikan bertujuan untuk mengatasi permasalahan yang mungkin timbul sebagai dampak dari perkembangan trend penyakit dan dampak dari penanganan penyakit tersebut. Selain itu antisipasi perawat juga berfokus pada peningkatan kualitas asuhan keperawatan, sehingga dapat mengatasi permasalahan yang ada, dan juga dapat menjawab tuntutan masyarakat akan pelayanan kesehatan khususnya pelayanan keperawatan yang berkualitas.

\section{BAHAN DAN CARA KERJA}

Tujuan penelitian ini adalah mengeksplorasi masalah atau diagnosa keperawatan yang terjadi pada klien kanker yang mendapatkan kemoterapi. Desain penelitian ini adalah qualitatif eksplorasi dengan pendekatan fenomenologi. Melalui pendekatan ini, peneliti mengeksplorasi bagaimana klien kanker yang mendapatkan kemoterapi menyampaikan pengalaman dan permasalahannya seputar dampak dari pemberian kemoterapi. Menurut Stephenson \& Corben (1997), pendekatan fenomenologi adalah pendekatan yang cukup kompleks, namun merupakan metodologi penelitian yang efektif dalam mengumpulkan dan menganalisa data untuk mengilustrasikan pengalaman hidup seseorang.

Sampel yang digunakan adalah non-probability sampling yaitu purposive sampling, di salah satu rumah sakit pemerintah di Jakarta. Sampel yang digunakan adalah klien kanker yang sedang mendapatkan kemoterapi seri pertama. Sampel yang dipilih hanya yang dapat berbahasa Indonesia dan dalam kondisi fisik yang cukup baik. Kondisi fisik diukur dengan menggunakan Karnofsky Performance Scale dan hanya mereka yang memiliki nilai $\geq 60 \%$ yang dilibatkan. Selain itu yang terpenting adalah berkeinginan untuk berpartisipasi dalam studi ini. Jumlah sampel yang berpartisipasi adalah 10 klien.

Pengambilan data dimulai dengan menjelaskan tujuan, manfaat, dan dampak penelitian ini. Peneliti kemudian meminta kesediaan responden dengan mengisi dan menandatangani lembar informed consent. Kegiatan dilanjutkan dengan wawancara terstruktur dan observasi. Observasi dilakukan selama 2 minggu. Keuntungan dari wawancara adalah pewawancara dapat meneruskan pada topik 
yang akan digali lebih jauh, namun pedoman wawancara yang baku memang harus ditetapkan sejak awal penelitian (Thomas, 1990). Peneliti menggunakan cara pengumpulan data yang berbeda (wawancara \& observasi) dalam rangka penggunaan metode triangulasi, seperti yang diuraikan Merton dan King (1990). Dengan metode ini hasil yang didapatkan akan lebih valid (Leininger, 1985).

Ketika proses wawancara berlangsung, selain menggunakan pedoman wawancara terstruktur, peneliti juga sekaligus mengobservasi respon nonverbal klien, lingkungan klien dan respon fisik klien terhadap pemberian kemoterapi. Penggabungan cara pengumpulan data ini akan meningkatkan nilai validitas dari hasil yang didapatkan (Holloway \& Wheeler, 1996).

\section{HASIL}

Profil demografik responden meliputi rentang pendidikan yaitu SMP sampai perguruan tinggi, berjenis kelamin pria dengan rentang usia 14-61 tahun. Diagnosa medis dari subyek adalah limfoma malignum hodgkin, limfoma malignum non hodgkin, anemia aplastik, dan leukemia limfoblastik akut. Kondisi fisik secara umum pada awal sebelum pemberian kemoterapi cukup baik. Data ini berasal dari beberapa contoh hasil laboratorium pada beberapa klien, meliputi fungsi umum ginjal, hati, pernafasan, dan jantung menunjukkan rentang normal. Kondisi fisik ini juga menjadi syarat utama klien sebelum terapi kemoterapi diberikan.

Secara umum setiap klien memiliki diagnosa keperawatan yang cukup beragam. Jumlah dan kualitas masalah yang terjadi pun berbeda, tergantung dari kondisi fisik dan mental klien. Sebanyak tujuh masalah keperawatan teridentifikasi melalui wawancara dan observasi. Masalah/ diagnosa keperawatan yang teridentifikasi pada sampel penelitian ini adalah (1) gangguan pemenuhan kebutuhan nutrisi berhubungan dengan penurunan nafsu makan dan mual, (2) gangguan keseimbangan cairan dan elektrolit berhubungan dengan muntah, (3) gangguan eliminasi: diare berhubungan dengan efek samping kemoterapi, (4) keterbatasan pemenuhan kebutuhan sehari-hari berhubungan dengan kelemahan, (5) gangguan integritas kulit \& rambut berhubungan dengan efek samping kemoterapi, (6) ketidakpastian berhubungan dengan penyakit yang dideritanya dan proses kemoterapi dan (7) gangguan konsep diri: gambaran diri rendah berhubungan dengan kerontokan rambut. Berikut ini satu persatu akan diuraikan diagnosa keperawatan yang teridentifikasi dari klien.

\section{Gangguan pemenuhan kebutuhan nutrisi berhubungan dengan penurunan nafsu makan dan mual}

Masalah gangguan pemenuhan kebutuhan nutrisi teridentifikasi dari munculnya data subyektif pada beberapa klien yang antara lain mengeluh mual dan rasa tidak nafsu makan.
“...kalau sudah datang penyakitnya (mual red.) udah deh rasanya ngeliat apa-apa nggak nafsu..” (R-1)
"Saya belum pernah merasakan mual seperti ini sebelumnya, rasa eneg (mual red.) yang amat sangat" (R-2)
"Gimana ya rasanya perut eneg, ngeliat makanan rumah sakit makin eneg" (R-4)

\section{Gangguan keseimbangan cairan dan elektrolit berhubungan dengan muntah}

Masalah lain yang dapat muncul dari kondisi mual klien tersebut adalah masalah risiko gangguan keseimbangan cairan sebagai akibat dari muntah yang terjadi dan akibat asupan cairan yang kurang. Masalah ini teridentifikasi karena didapatkannya data obyektif klien mengalami muntah saat atau segera setelah makan atau minum, seperti yang dituturkan oleh responden $2 \& 9$ :

\footnotetext{
"kadang ....baru minum udah muntah....makan apalagi...." (R-2)

"Pernah kemaren panas banget badan....mau minum takut muntah.." (R-9)

Data lain yang didapatkan adalah lima dari sepuluh klien mengalami peningkatan suhu tubuh dengan rentang peningkatan suhu tubuh antara $38^{\prime} \mathrm{C}$ sampai 39,2'C (lihat tabel 1).
} 
Jurnal Keperawatan Indonesia, Volume 8, No. 1, Maret 2004; 1-7

Tabel 1

Persentase peningkatan suhu tubuh sebelum dan sesudah kemoterapi $(n=10)$

\begin{tabular}{crrrr}
\hline $\begin{array}{c}\text { Peningkatan suhu } \\
\text { tubuh }\end{array}$ & \multicolumn{2}{c}{$\begin{array}{c}\text { Sebelum } \\
\text { kemoterapi }\end{array}$} & \multicolumn{2}{c}{$\begin{array}{c}\text { Setelah } \\
\text { kemoterapi }\end{array}$} \\
\hline $38^{\circ} \mathrm{C}-39^{\circ} \mathrm{C}$ & Frekuensi & Persen & Frekuensi & Persen \\
\hline$>39^{\circ} \mathrm{C}$ & 1 & 10 & 3 & 30 \\
\hline Total & 0 & 0 & 2 & 20 \\
\hline
\end{tabular}

\section{Gangguan eliminasi: diare/ konstipasi} berhubungan dengan efek samping kemoterapi

Pada sebagian klien yang mendapatkan jenis kemoterapi tertentu, mereka mengalami keluhan diare pada saat eliminasi. Keluhan ini disampaikan oleh tiga responden.

"Abis dapet infus (yang dimaksud klien adalah kemoterapi) berak saya jadi mencret..." (R-6)

"Makan sekarang nggak bisa sembarangan, perut saya lagi nggak beres, mencret..." (R-10)

"Udah nggak ke belakang......berak, sejak 3 hari yang lalu, mulai masuk obatnya deh....." (R-9)

\section{Keterbatasan pemenuhan kebutuhan sehari-hari berhubungan dengan kelemahan}

Diagnosa keperawatan gangguan pemenuhan kebutuhan sehari-hari (sebagian) teridentifikasi dari adanya keluhan klien lemah/ lemas dan klien banyak meminta bantuan keluarga untuk memenuhi beberapa kebutuhan klien, seperti makan, minum, kebersihan diri, dan eliminasi. Keluhan ini hampir dikeluhkan oleh semua responden, seperti yang disampaikan oleh responden:

"aduh rasanya capek banget nih badan....kalo lagi nggak muntah juga rasanya capek." (R-3)

Kondisi umum klien ini tampak lemah, agak pucat dengan akral dingin. Tanda tanda vital klien (tabel 2) umumnya menunjukkan peningkatan nadi yang berkisar antara 112-124 kali permenit, dengan tekanan darah antara 110/ 70-130/80 $\mathrm{mmHg}$.
Tabel 2

Persentase Perubahan tanda tanda vital 1 dan 3 hari post kemoterapi $(n=10)$

\begin{tabular}{lrrrr}
\hline $\begin{array}{c}\text { Perubahan tanda- } \\
\text { tanda vital }\end{array}$ & \multicolumn{2}{c}{$\begin{array}{c}\text { 1 hari post } \\
\text { kemoterapi }\end{array}$} & \multicolumn{2}{c}{$\begin{array}{c}\text { 3 hari post } \\
\text { kemoterapi }\end{array}$} \\
\hline Tekekuensi & Persen & Frekuensi & Persen \\
\hline Frekuensi pernafasan & 4 & 40 & 8 & 80 \\
\hline Denyut nadi & 5 & 50 & 8 & 60 \\
\hline
\end{tabular}

\section{Gangguan integritas kulit \& rambut berhubungan dengan efek samping kemoterapi}

Keluhan rambut rontok dan kulit kering dikeluhkan oleh beberapa klien dimana klien menyadari tiga hari setelah pemberian kemoterapi.

"Rambut saya rontok kalo disisir, kekerasan nyisirnya kali...." (R-8)

"Kulit jadi item, kering. Perih kalo dipegang kenceng..." (R-9)

\section{Ketidakpastian berhubungan dengan penyakit yang dideritanya \& proses kemoterapi}

Ketidakpastian adalah diagnosa keperawatan yang sering terjadi pada klien yang diobservasi. Diagnosa ini teridentifikasi dari adanya keluhan takut klien akan dampak dari penyakitnya. Umumnya klien bertanya-tanya apakah nantinya klien akan sembuh, apakah pengobatan menjamin klien terbebas dari penyakitnya dan keluhan-keluhan yang muncul karena pemberian kemoterapi. Kadangkadang klien tampak murung dengan tatapan kosong.

"saya nanti bisa sembuh nggak sih..., saya pernah baca ada yang bilang begini ada yang bilang begitu.. saya jadi takut" (R-8)

\section{Gangguan Konsep Diri: Gambaran Diri Rendah Berhubungan Dengan Kerontokan Rambut}

Tidak semua klien, terutama klien pria mudah untuk mengungkapkan perasaannya. Oleh karena itu, pada penelitian ini rasa saling percaya perlu dijalin 
sehingga masalah psikososial mudah untuk di identifikasi. Gambaran diri yang rendah akibat rambut rontok dikeluhkan oleh satu responden yang memang mengalami kerontokan rambut:

"Ya....saya malu juga sih, udah sakit, botak lagi........." (R-8)

Dari ke 7 diagnosa keperawatan tersebut terdapat 3 diagnosa yang sering muncul pada klien/ responden. Diagnosa tersebut dapat dilihat pada tabel 3. Diagnosa keperawatan utama yang sering muncul yaitu: gangguan pemenuhan kebutuhan nutrisi: kurang berhubungan dengan penurunan nafsu makan \& mual, keterbatasan pemenuhan kebutuhan sehari-hari berhubungan dengan kelemahan dan ketidakpastian berhubungan dengan penyakit yang dideritanya dan proses kemoterapi.

Tabel 3

Frekuensi Diagnosa Keperawatan yang sering muncul pada Klien Keganasan Hematologi yang mendapatkan Kemoterapi

\begin{tabular}{|c|c|c|c|}
\hline \multirow[t]{2}{*}{ No } & \multirow{2}{*}{$\begin{array}{l}\text { Diagnosa } \\
\text { keperawatan }\end{array}$} & \multicolumn{2}{|c|}{3 hari post kemoterapi } \\
\hline & & $\begin{array}{l}\text { Frekuensi } \\
\quad(\mathrm{n}=10)\end{array}$ & Persentase \\
\hline 1 & $\begin{array}{l}\text { Gangguan pemenuhan kebu- } \\
\text { tuhan nutrisi: kurang berhu- } \\
\text { bungan dengan penurunan } \\
\text { nafsu makan \& mual }\end{array}$ & 8 & $80 \%$ \\
\hline 2 & $\begin{array}{l}\text { Risiko gangguan keseim- } \\
\text { bangan cairan dan elektrolit }\end{array}$ & 3 & $30 \%$ \\
\hline 3 & $\begin{array}{l}\text { Keterbatasan pemenuhan } \\
\text { kebutuhan sehari-hari berhu- } \\
\text { bungan dengan kelemahan }\end{array}$ & 7 & $70 \%$ \\
\hline 4 & $\begin{array}{l}\text { Gangguan integritas kulit \& } \\
\text { rambut berhubungan dengan } \\
\text { efek samping kemoterapi }\end{array}$ & 1 & $10 \%$ \\
\hline 5 & $\begin{array}{l}\text { Gangguan eliminasi: diare atau } \\
\text { konstipasi berhubungan dengan } \\
\text { efek samping kemoterapi }\end{array}$ & 3 & $30 \%$ \\
\hline 6 & $\begin{array}{l}\text { Ketidakpastian berhubungan } \\
\text { dengan penyakit yang diderita- } \\
\text { nya \& proses kemoterapi }\end{array}$ & 7 & $70 \%$ \\
\hline 7 & $\begin{array}{l}\text { Gangguan konsep diri: } \\
\text { gambaran diri rendah ber- } \\
\text { hubungan dengan kerontokan } \\
\text { rambut }\end{array}$ & 1 & $10 \%$ \\
\hline
\end{tabular}

\section{PEMBAHASAN}

Berdasarkan hasil wawancara dan observasi telah teridentifikasi 7 masalah/ diagnosa keperawatan yang terdapat pada 10 klien yang mendapatkan kemoterapi. Secara umum kesepuluh klien mengalami masalah gangguan pemenuhan kebutuhan nutrisi. Diagnosa nutrisi ini termasuk 3 diagnosa yang sering terjadi pada responden dan dialami pada 8 dari 10 responden. Derajat gangguan pemenuhan kebutuhan nutrisi pada ke delapan klien ini berbeda-beda, dari ringan (keluhan mual) sampai berat (muntah saat atau sesudah makan). Derajat yang berbeda ini dimungkinkan terjadi karena kondisi fisik klien yang berbeda pula.

Namun masalah gangguan nutrisi ini didukung oleh hasil penelitian dari Perry \& Yarbro (1984) yang menyatakan bahwa mual dan muntah merupakan gejala yang sering muncul pada klien yang mendapatkan kemoterapi, yang terjadi segera setelah kemoterapi, beberapa jam sampai beberapa hari setelah kemoterapi. Hal ini didukung pula oleh pendapat perawat yang merawat klien bahwa klien sering mengeluhkan mual dan muntah saat pemberian kemoterapi (Waluyo, 1999).

Lum et.al. (1978) menambahkan bahwa kondisi fisik klien yang mendapatkan kemoterapi sangat mempengaruhi respon tubuh terhadap pemberian kemoterapi. Selain itu, jenis dan dosis kemoterapi yang diberikan berpengaruh pada keluhan mual dan muntah yang dialami klien (Dodd \& Mood, 1981). Dengan demikian masalah nutrisi ini merupakan masalah penting yang dapat menurunkan kualitas hidup (quality of life) dari klien yang mendapatkan kemoterapi (Wickham, 1999).

Risiko gangguan keseimbangan cairan merupakan diagnosa keperawatan kedua yang terjadi pada klien yang diobservasi. Masalah ini muncul akibat muntah dan peningkatan suhu tubuh klien. Pengeluaran cairan berlebihan (muntah) menimbulkan keseimbangan cairan masuk dan keluar berisiko untuk terjadi balans negatif. Peningkatan suhu tubuh juga dapat mencetuskan pengeluaran cairan melalui evaporasi, yang dapat berisiko untuk terjadi balans negatif jika tidak diimbangi dengan pemasukan yang cukup. 
Craig dan Powell (1987) menyatakan hal yang senada tentang dampak mual dan muntah. Menurut mereka, mual dan muntah dapat berakibat risiko gangguan keseimbangan cairan meningkat, selain dapat mengakibatkan malnutrisi. Pendapat mereka sekaligus menunjang hasil yang didapat dari penelitian ini bahwa mual dan muntah dapat memunculkan masalah pemenuhan kebutuhan nutrisi. Seperti yang terjadi pada masalah nutrisi, masalah keseimbangan cairan tubuh dipengaruhi jenis dan dosis kemoterapi yang diberikan (Dodd \& Mood, 1981), serta frekuensi muntah yang terjadi pada klien. Muntah sendiri menurut Doherty (1999) dapat dipengaruhi oleh kecemasan klien, dan pengalaman klien terhadap muntah.

Diagnosa gangguan pemenuhan kebutuhan sehari-hari sangat berkaitan dengan kelemahan yang terjadi. Kelemahan klien yang diobservasi umumnya terjadi karena adanya gangguan status nutrisi akibat minimnya masukan nutrisi. Masukan nutrisi ini sangat dipengaruhi oleh nafsu makan dan kemampuan klien makan. Hal ini dipersulit oleh adanya mual dan muntah yang terjadi pada sebagian klien (Wilkes, 1996).

Ketidakpastian (uncertainty) yang terefleksikan melalui kecemasan yang terobservasi pada klien terutama disebabkan karena proses penyakit yang dideritanya. Data ini tergali setelah hubungan saling percaya antara perawat klien telah terjalin. Kecemasan timbul sejak saat klien menyadari dirinya terkena kanker. Setiap individu yang mendapatkan dirinya terkena penyakit serius akan mengalami suatu fase kecemasan yang tinggi (McLaughin, 1998).

Kecemasan akibat ketidakpastian ini dapat berlanjut dengan adanya reaksi tubuh terhadap pengobatan. Kecemasan ini dapat diperburuk dengan tidak lancarnya komunikasi yang terjadi antara klien dengan tim kesehatan (McLaughin, 1998). Seyogyanya klien telah terinformasi secara baik bahwa dari pengobatan kemoterapi ini, selain memiliki efek kuratif juga memiliki efek samping yang cukup serius. Informasi yang memadai dapat membentuk harapan klien atas pengobatan kemoterapi ini menjadi lebih rasional. Pendapat ini didukung oleh penelitian terdahulu tentang pendapat perawat pada perawatan klien kanker, bahwa klien sering kurang mendapatkan informasi yang diperlukan tentang kondisi, proses perawatan, dan pengobatannya (Waluyo, 1999).

Lebih dari separuh responden pada penelitian ini adalah klien dewasa muda dan dalam usia produktif yaitu yang berusia antara 35-45 tahun. Usia ini mungkin dapat berpengaruh terhadap daya tahan tubuh klien. Walaupun demikian, dampak kemoterapi secara umum akan menurunkan daya tahan tubuh akibat dari depresi sumsum tulang belakang, seperti yang diuraikan oleh Brandt, (1984). Namun, penelitian Blesch (1988) mengimplikasikan bahwa banyak klien lanjut usia masih mampu bertahan dengan pemberian kemoterapi.

Observasi dan wawancara yang dilakukan pada penelitian ini adalah pada minggu pertama dan kedua pemberian kemoterapi. Seperti yang pernah diobservasi oleh Bersagel (1971) dan Braine (1980) di paparkan bahwa depresi pertahanan tubuh dimulai pada hari 4-5 dan memuncak pada akhir minggu ke dua. Namun respon tubuh ini sangat tergantung dari jenis dan dosis kemoterapi yang diterima oleh klien.

Wilkes (1996) melengkapi faktor faktor yang mempengaruhi respon tubuh terhadap pemberian kemoterapi. Faktor-faktor tersebut antara lain status nutrisi klien, kondisi (cadangan) sumsum tulang belakang, kemampuan tubuh memetabolisme obat, terapi sebelumnya dan waktu paruh kemoterapi. Faktor yang cukup kontroversial adalah kesalahan pemberian kemoterapi termasuk dalam aspek yang mungkin mempengaruhi respon klien terhadap kemoterapi (Schulmeister, 1999). 


\section{KESIMPULAN}

Dari studi ini terlihat adanya 3 masalah/ diagnosa keperawatan utama pada klien kanker yang mendapatkan kemoterapi. Ketiga diagnosa keperawatan ini terdapat pada sekumpulan diagnosa keperawatan yang terdapat pada studi kepustakaan. Di samping kemiripannya, terdapat perbedaan antara hasil penelitian ini dengan kepustakaan yaitu 4 diagnosa yang dijelaskan pada studi kepustakaan tidak diperoleh pada penelitian ini. Hal tersebut dapat terjadi karena berbagai faktor yang dapat mempengaruhinya.

Faktor-faktor yang mungkin mempengaruhi perbedaan diagnosa keperawatan pada penelitian ini dan pada studi kepustakaan antara lain usia, dosis dan jenis obat, status nutrisi klien, kondisi sumsum tulang belakang, kemampuan tubuh memetabolisme obat, pengobatan sebelumnya, waktu paruh obat kemoterapi, tingkat kecemasan klien, dan dukungan keluarga (EN).

* Agung Waluyo, S.Kp., M.Sc.: Staf pengajar bagian keperawatan medikal bedah FIK-UI

\section{KEPUSTAKAAN}

Bersagel, D.E. (1971). Assesment of massive dose chemoterapy of malignant disease. Canadian Medical Association Journal. 104: 31-36

Blesch, K.S. (1988). The normal physiological changes of aging and their impact on the response to cancer treatment. Seminar On Oncology Nursing. 4(3): 178-188

Braine, H.G. (1980). Infectious complications of granulocytopenia after cancer chemotherapy: Complication of cancer: Diagnosis and management. Baltimore: The Johns Hopkins University Press, 152

Brandt, B., (1984). A nursing protocol for client with neutropenia. Oncology Nursing Forum 11(2): 24-28

Copstead, L.C. \& Banasik, J.L. (2000). Pathophysiology biological \& behavioral perspectives. $\left(2^{\text {nd }} \mathrm{ed}\right)$. Philadelphia: WB Saunders.
Craig, J.B. \& Powell, B.L. (1987). Review: The management of nausea $\&$ vomiting in clinical oncology. American Journal Of Medical Sciences. 293(1): 34-41

Dodd, M.J. \& Mood, D.W. (1981). Chemotherapy:helping patients to know the drugs they are receiving and their possible effects. Cancer Nursing. 4: 311-318

Doherty, K.M. (1999). Closing the gap in prophylactic antiemetic therapy: Patient factors in calculating the emetogenic potential of chemotherapy. Clinical Journal Of Oncology Nursing 3(3): 113-118

Holloway, I. \& Wheeler, S. (1996). Qualitative research for nurses. London: Blackwell Science.

Leininger, M. (1985). Qualitative research methods in nursing. New York: Grune \& Stratton.

Lum, J.L.J., et al. (1978). Nursing care of oncology patients receiving chemotherapy. Nursing Research. 27: 340-346

Mc Laughlin, M. (1998). Principle in chemoterapy., practical oncology, aLange clinical manual Philadelphia: Appleton \& Lange.

Merton, R.K. \& King, R. (1990). The focused interview: A manual of problems and procedures. ( $2^{\text {nd }}$ ed.). New York: Free Press.

Perry, M.C. \& Yarbro, J.W. (1984). Toxicity of chemotherapy. New York: Grunne and Stratton

Schulmeister, L. (1999). Chemoteraphy medication errors: description, severity and contributing factors. Oncology Nursing Forum 26 (6): 1033-1042

Stephenson, N. \& Corben, V. (1997). Research mindedness for practice, an interactive approach for nursing and health care. London: Churchill Livingstone.

Sutandio, N. (1999). Farmakologi sitostatika \& hubungannya dengan siklus sel. Pelatihan keperawatan kemoterapi, tidak dipublikasikan

Thomas, B.S. (1990). Nursing research: An experiential approach. St. Louis: Mosby Company.

Waluyo, A. (1999). Persepsi perawat terhadap implementasi konsep self-care pada klien kanker. Disertasi S-2, Liverpool JMU, tidak dipublikasikan

Wickham, R.S., et.al. (1999). Taste changes experienced by patients receiving chemoterapy. Oncology Nursing Forum. 24(4): 697-706

Wilkes, G.M., et.al. (1996). Oncology nursing drug reference. Boston: John \& Bartlett 